\title{
HAK WARISAN DAN HUBUNGANNYA DENGAN DAHA TUA MENURUT HUKUM ADAT BALI
}

\author{
Oleh :

\section{Ni Ketut Sri Ratmini}

\begin{abstract}
This study aims to answer the question of how the law of inheritance and relationship with daha tua under customary law Bali. After doing legal research by reviewing a number of normative rules of customary law relating to inheritance and the results were analyzed with the theory of the legal system, justice theory and feminist theory, then we can conclude the nature of inheritance under customary law Bali is the process of transfer of the assets, debts, obligations and the responsibility of the heir to the heir to consider whether the position as purusa or not as Purusa.

This is in accordance with the kinship system adopted by indigenous people in Bali are patrilineal, where applicable three inheritance system that is individual, collective and mayorat. Daha tua in Bali inheritance under customary law is largely determined by its status as Purusa or not. Daha tua is purusa, if it does not have siblings (only child), where his right to inheritance is the same as a boy with the status of Purusa.

If the status is not an daha tua purusa then heritage inadmissibility under customary law as contained in the Bali awig awig and Main Assembly decision Pakraman (MUDP) is the same as the young women who have not married, are only entitled to use the property in order to get rich from their parents as the soul of funds or property that are used to maintain its viability. Subsequent developments MUDP Assembly decided, a woman is entitled to receive half of the inheritance rights purusa after the third cut to inheritance and preservation of the interests of all the women were not converted and lawlessness on their parents. Inheritance received daha parents also depends on the role of the structure that has the authority to regulate the provision of such heritage Pakraman and Village Main Assembly. Furthermore, it is suggested to indigenous villages are advised to adopt decisions in the Great Assembly awig awig as stated in the decision Majelis Utama Desa Pakraman.
\end{abstract}

Keywords: Daha Tua, Inheritance, Bali Customary Law.

\section{PENDAHULUAN}

\subsection{Latar Belakang Masalah}

Perempuan yang tidak kawin disebut daha tua. Kehidupan mereka menjadi perhatian ketika kemampuannya dalam bidang ekonomi dianggap mampu, meyebabkan mereka akan disayang oleh kerabatnya. Sebaliknya ketika mereka tidak cukup mampu dalam bidang ekonomi, apalagi tidak mampu berinteraksi dengan baik maka ada kecendrungan mereka akan terabaikan atau anggota keluarga akan menganggapnya sebagai beban. Keadaan dalam keluarga seperti ini seringkali mengantarkandaha tua ke panti sosial yang bertugas memelihara para lanjut usia. Hal ini disebabkan karena daha tua tidak memiliki anak yang bertanggung jawab untuk menunjang kelangsungan hidupnya. Ketika 
adadaha tuayang disayang dan diajak hidup bersama di rumah, alasan dipertahankannya daha tua ini supaya kelak ketika meninggal dunia, hartanya bisa dinikmati oleh anggota keluarga lainnya.

Dalam budaya Bali perempuan memiliki peran yang sangat strategis memelihara tetap ajegnya budaya Bali yang dilandasi oleh ajaran agama Hindu baik di lingkungan keluarga maupun masyarakat yang lebih luas. Bahkan dapat dikatakan perempuan adalah tulang punggung kegiatan keagamaan sehingga tanpa keterlibatan perempuan, kegiatan keagamaan tidak dapat berlangsung. Hal ini disebabkan oleh karena ritual agama yang dilakukan sebagian besar adalah hasil gotong royong kaum perempuan, tidak saja dalam proses pengerjaannya, namun juga pembiayaan pembuatan ritual keagaamaan inipun juga ikut ditanggung oleh pihak perempuan. Keberadaan perempuan yang sangat sentral dalam kehidupan masyarakat adat di Bali sesungguhnya tidak dapat diingkari, dan hal ini semestinya menghilangkan mind set perempuan dinomor duakan. Kenyataan ini bisa dilihat dari bagaimana perlakuan pembagian warisan yang diterima oleh perempuan Bali. Keadaan seperti ini tentunya tidak terlepas dari ideologi patriarkhi yang dianut dalam sistem kekeluargaan masyarakat adat di Bali yang membuat sepertinya eksistensi perempuan Bali disepelekan.. hak-hak perempuan. seperti tidak dianggap penting terhadap isu-isu aktual pada kebiasaan masyarakat adat. Dalam rangka mewujudkan kesetaraan gender dalam kehidupan masyarakat di Bali terkendala pengaruh ideologi patriarkhi yang kuat, yakni dominasi dari laki-laki dalam hal kekuasaan pada saat pengambilan keputusan sehingga melahirkan hubungan kekuasaan yang dominatifdan sub-ordinatif. ${ }^{1}$ Kehidupan masyarakat adat Bali bahkan memiliki kecenderungan untuk mempertahankan kuatnya hegemoni patriarkhi ini secara tidak sadar dan menganggapnya sebagai sesuatu yang wajar oleh kaum laki-laki, bahkan kaum perempuan pun sepertinya mendukung hegemoni tersebut terus berlangsung secara turun temurun. ${ }^{2}$

Adanya laki-laki dan perempuan yang disimpulkan menjadi purusa dan pradana merupakan gambaran dua hal yang harus diseimbangkan supaya terjadi hubungan yang harmonis. Hal ini tidak terlepas dari keberadaan bumi dan langit, energi positif dan negatif, yang juga bisa diwakilkan dengan istilah purusa dan pradana. Hubungan yang harmonis bisa rusak karena dikotori oleh keinginan untuk menang sendiri oleh salah satu pihak, terutama ketika dilaksanakan pembagian warisa.Purusa yang diidentikan dengan laki-laki dipahami kurang tepat sebagaipenguasa, yang lebih kuat sehingga dapat menentukan bagaimana pembagian warian itu dilakukan seperti yang sering terjadi dalam masyarakat pada umumnya dimana yang lemah berada pada posisi untuk melayani apa yang menjadi keinginan kelompok yang dipandang lebih kuat..Pentingnya posisi laki-laki sebagai akibat adanya tradisi atau anggapan bahwa laki-laki memiliki tanggung jawab terhadap keberlangsungan tradisi kelompok. Hal

Ni Nyoman Sukerti, 2012, Hak Mewaris Perempuan Dalam Hukum Adat Bali Sebuah Studi Kritis, Udayana University Press, Denpasar, hlm.81.

Ibid. 
ini bertentangan dengan kenyataan yang terjadi di masyarakat, dimana perempuan lebih banyak melaksanakan tradisi yang diwariskan oleh leluhur.

Keluarga dalam masyarakat adat Bali sering merasa khawatir dan bahkan ada yang menganggap sebagai suatu malapetaka apabila dalam sebuah keluarga tidak dapat memiliki keturunan laki-laki atau dalam keluarga tersebut hanya mempunyai keturunan perempuan. ${ }^{3}$ Pada masyarakat adat Bali yang menganut sistem perkawinan patrileneal anak perempuan pada umumnya tidak berkedudukan sebagai penerus garis keturunan pada keluarga bapaknya, dimana perempuan ini memiliki saudara laki-laki. Pada saat anak perempuan ini kawin keluar, haknya terhadap warisan orang tuanya menjadi hilang, dimana harta orang tuanya selanjutnya akan diwariskan pada saudara laki-lakinya. Keadaan ini menjadi alasan mengapa anak laki-laki kemudian mengambil alih tanggung jawab untuk melaksanakan kewajiban membayar utang orang tuanya, dan melaksanakan kewajiban melakukan upacara ngaben untuk orang tuanya pada saat meninggal nanti. Namun bagi anak lakilaki yang memiliki karakter penyayang tidak akan bersikap serakah dengan mengabaikan saudara perempuannya. Anak laki-laki ini dapat saja berbagi harta warisan orang tuanya dengan saudara perempuannya, apabila saudara laki-lakinya ini dapat secara ikhlas memberikannya apakah dengan bagian yang sama atau tidak. Anak perempuan tetap

Made Aripta Wibawa, 2006, Wanita Hindu Sebuah Emansipasi Kebablasan, PT. Empat Warna Komunikasi, Denpasar, hlm.98. mendapatkan hak warisan apabila tidak kawin keluar atau melakukan perkawinan dengan sistem nyentana dimana perempuan berstatus purusa sedangkan suaminya berstatus pradana ${ }^{4}$ Perempuan dapat saja berstatus sebagai purusa apabila dilakukan perkawinan dengan sistem perkawinan nyentana, dimana suaminya yang berstatus sebagai pradana akan tinggal bersama dengan keluarga dari istrinya yang bersatus sebagai purusa. Pada kasus yang lain orang tua dapat saja memberikan sebagian hartanya kepada anak perempuan yang kawin keluar sebagai bekal dalam mengarungi kehidupan berkeluarga. Harta ini dapat saja berupa mobil, sepeda motor, atau mungkin perhiasan. Harta yang dibawa oleh perempuan yang kawin keluar inilah yang disebut sebagai harta bawaan (tetatadan)

Dewasa ini pewarisan pada masyarakat adat Bali telah mengalami perkembangan khususnya terhadap persamaan hak dalam pewarisan bagi perempuan Bali yang telah diatur dalam Keputusan Majelis Utama Desa Pakraman Bali (MUDP) Bali No. 01/ KEP/PSM-3/MDP Bali/X/2010, tanggal 15 oktober 2010, tentang hasil-hasil Pasamuhan Agung III MUDP Bali, yang memutuskan hak dan kewajiban anak yang melangsungkan perkawinan terhadap harta warisan yang didalamnya terdiri atas harta pusaka dan harta gunakaya,hal lain yang diputuskan adalah bagaimana hak waris anak perempuan baik itu anak kandung maupun anak angkat. Berikut ini dijelaskan singkat mengenai hak waris anak perempuan menurut Keputusan Majelis Utama Desa Pakraman Bali (MUDP)

Ibid.hlm.99. 
Bali No.01/KEP/PSM- 3/MDP Bali/X/2010 adalah sebagai berikut :

"Sesudah 2010 wanita Bali berhak atas warisan berdasarkan Keputusan Pasamuhan Agung III MUDP (Majelis Utama Desa Pakraman) Bali No. 01/ KEP/PSM-3/MDP Bali/X/2010, 15 Oktober 2010. Wanita Bali menerima setengah dari hak waris purusa setelah dipotong 1/3 untuk harta pusaka dan kepentingan pelestarian. Hanya jika kaum wanita Bali yang pindah ke agama orang lain, mereka tidak berhak atas hak waris. Jika orangtuanya ikhlas, tetap terbuka dengan memberikan jiwa danaatau bekal sukarela". ${ }^{5}$

Mencermati berbagai fenomena mengenai adanya ketimpangan dan diskriminasi terhadap perempuan dalam masyarakat adat Bali, penulis menjadi tertarik untuk meneliti secara lebih spesifik lagi mengenai bagaimana hukum warisan dan hubungannya dengan daha tua menurut hukum adat Bali.

\subsection{Rumusan Masalah}

Berdasarkan latar belakang masalah sebagaimana diuraikan di atas, maka dapat dirumuskan permasalahan bagaimanakah hukum warisan dan hubungannya dengan daha tua menurut hukum adat Bali.

\subsection{Tujuan Penelitian}

Penelitian ini bertujuan untuk mengembangkan kemampuan berpikir secara konseptual dalam rangka mengetahui

Majelis Utama Desa Pakraman (MUDP) Bali, 2010, Himpunan Hasil-Hasil Pasamuhan Agung III MDP Bali, MUDP, Denpasar, hlm.43. dan menganalisa hukum warisan dan hubungannya dengan daha tua menurut hukum adat Bali, dengan cara mencermati dan mengkaji literatur-literatur yang berkaitan dengan warisan menurut hukum adat Bali menggunakan teori-teori yang didapat dalam perkuliahan.

\subsection{Metode Penelitian}

\subsubsection{Jenis Penelitian}

Jenis penelitian yang digunakan dalam penulisan ini adalah penelitian hukum normatif, yang mengkaji asasasas hukum adatmengenai hukum warisan dan hubungannya dengan daha tuamenurut hukum adatBali baik secara tertulis maupun tidak tertulis. Penelitian ini akan menggunakan dua pendekatan yaitu pendekatan historis dan pendekatan konseptualuntukmenganalisis permasalahan hukum warisan dan hubungannya dengandaha tuamenurut hukum adatBali. Pendekatan historisdigunakan untuk mendapatkan gambaran mengenai hak waris perempuan khususnya daha tua dari buku-buku yang membahas mengenai hal itu sehingga dapat diketahui bagaimana perkembangannya sampai saat ini dari kontek sejarah. Dari pendekatan ini dapat dilihat pola bekembangnya hak waris perempuan khususnya Daha Tua dari dulu sampai sekarang. Pendekatan konseptual yang digunakan dalam penelitian ini diharapkan dapat menguraikan mengenai siapa saja yang disebut daha tua, bagaimana kedudukannya secara hukum dalam masyarakat adat Bali, serta bagaimana konsekuensi kedudukannya itu terhadap warisan yang bisa didapatkannya. Disinilah diperlukan pendekatan konseptual sebagai 
landasan berpikir dalam menganalisis permasalahan. Bahan hukum yang dikaji dan yang dianalisis dalam penelitian hukum normatif terdiri dari bahan hukum primer, bahan hukum sekunder, dan bahan hukum tersier. $^{6}$

\section{HASIL DAN PEMBAHASAN}

Hukum warisan dapat dipahami dengan lebih baik melalui hakekat warisan itu sendiri. Pengertian hakekat menurut kamus besar bahasa Indonesia adalah kebenaran, kenyataan, yang sebenarnya. ${ }^{7}$ Pengertian hakekat menurut Jalius HR. adalah berupa apa yang membuat sesuatu terwujud. Hakekat adalah unsur inti atau pokok yang menyebabkan sesuatu dapat diwujudkan, merupakan unsur yang harus dan wajib ada. Unsur inti inilah yang memberikan makna terdalam yang merupakan cirikhas yang tidak dapat diingkari. Hakekat yang merupakan inti ini yang memberikan nilai-nilai dasar pada sesuatu yang ingin dijelaskan. Setiap kalimat yang dibuat akan menguatkan hakekat yang ingin dibangun dalam sebuah wacana yang ingin dibangun. Hakekat ini wajib ada karena merupakan unsur utama yang didukung unsur-unsur lain yang hanya sebagai pelengkap untuk menguatkan hakekat dalam hal ini dapat disebut sebagai makna. Kalimat sederhananya hakikat itu adalah pokok atau inti dari yang ada. ${ }^{8}$

Peter Mahmud Marzuki, 2008, Penelitian Hukum, Kencana Prenada Media Group, Jakarta, hlm.141.

Suharso dan Ana Retno Ningsih, 2014, Kamus Besar Bahasa Indonesia, Edisi Lux, CV. Widya Karya, Semarang, hlm.161.

8 Jalius HR, Pengertian Hakekat, https://jalius12. wordpress.com/2010/12/06/pengertian-hakekat/ diakses 31 Mei 2015
Berkaitan dengan warisan yang hakekatnya adalah peninggalan diatur dalam hukum waris adatyang memuat aturan-aturan yang memberikan petunjuk bagaimana proses meneruskan dan pengambilalihan harta warisan berupa benda dan berupa harta yang tidak berwujud dari suatu angkatan manusia kepada turunannya. ${ }^{9}$ Jadi dapat dipahami bahwa hukum waris terdiri dari norma dan azas yang berhubungan dengan proses pengalihan dan penerusan harta kekayaan yang mencakup harta benda material dan non material dari pewaris kepada ahli waris. Harta warisan material ini tentunya yang memiliki nilai ekonomi dapat berupa uang, tanah, rumah, saham, asuransi, tabungan, dan deposito. Harta warisan non material adalah harta yang dapat dikatakan tidak memiliki nilai ekonomi namun berupa kewajiban kepada orang tua, keluarga, dan masyarakat. Proses pewarisan ini dapat dilakukan pada saat pewaris masih hidup ataupun telah meninggal dunia. Kejadian atau proses ini akan terjadi berulang-ulang, sehingga keturunannya ini akan berkembang menjadi keluarga mandiri, yang nantinya juga akan melaksanakan proses pewarisan ini kepada keturunannya.Pewarisan ini tidak menjadi terhambat ketika orang tua pewaris telah meninggal dunia, karena itu penerusan atau pengambil alihan harta warisan yang terdiri dari harta berwujud dan tidak berwujud dapat saja terus dilakukan. ${ }^{10}$

Khusus dalam masyarakat adat di Bali penerusan harta warisan dimulai pada

\footnotetext{
Soepomo, 2000, Bab-Bab Tentang Hukum Adat, Pradnya Paramita, Jakarta, hlm.84.

10 Wirjono Prodjodikoro, 1986, Asas-Asas Hukum
} Pidana Indonesia, PT.Eresco Bandung, hlm.41. 
saat pewaris telah meninggal dunia dan telah dilakukan upacara pengabenan. ${ }^{11}$ Pada masyarakat Bali proses pewarisan baru dapat dilakukan setelah pewaris meninggal dunia dan telah dilakukan upacara pengabenan. Ketika terjadinya proses pewarisan, dimulailah mengumpulkan semua harta kekayaan peninggalan yang akan diwariskan kepada ahli waris.Korn berpendapat dalam bukunya Panetje bahwa hukum pewarisan adalah merupakan salah satu bagian yang paling sulit pada hukum adat Bali. Adapun penyebab kesulitan tersebut adalah karena adanya perbedaan-pebedaan dari daerah - daerah yang ada di Bali mengenai warisan yang didapatkan oleh ahli waris. Perbedan itu menyangkut harta apa saja yang boleh diwariskan, perbedaan bagian yang diperoleh oleh ahli waris dan putusan-putusan yang diputuskan oleh pengadilan adat. ${ }^{12}$ Paswara Residen Bali dan Lombok tahun 1900, mengenai pewarisan memberikan ketentuan yang berbeda, dimana harta yang akan diwariskan merupakan harta kekayaan yang masih setelah dipotong untuk dipergunakan membayar hutang dan biaya proses dilakukannya pewarisan. Ahli warisan dibagikan harta warisan dalam porsi yang sama, tidak hanya harta warisan namun juga mengenai kewajiban terhadap pemeliharaan puri, pemerajan dan adat pun dibagi sama rata. Hal ini cenderung dapat dipenuhi oleh Pengadilan Negeri manakala terjadi tuntutan yang seperti itu. ${ }^{13}$

Soeripto, 1983, Beberapa Bab tentang Hukum Adat Bali, Fakultas Hukum Fakultas Hukum Universitas Negeri Jember, Jember, hlm.49.

12 Gde Panetje, Aneka Catatan Tentang Hukum Adat Bali, CV. Kayumas Agung, Denpasar, hlm.101.

13 ibid, hlm.106.
Sistem hukum waris yang dikenal oleh masyarakat Indonesia adalah sistem hukum waris adat, sistem hukum waris Islam dan sistem hukum waris menurut KUH Perdata. Menurut Ter Haar, ${ }^{14}$ hukum waris adat merupakan hukum yang berhubungan dengan berlangsungnya penerusan dan pengalihan harta warisan yang bersifat material maupun inmaterial dari satu keturunan kepada keturunan berikutnya yang dilakukan sesuai dengan aturan yang berlaku pada masyarakat adat Bali. Pewarisan mengandung kaidah hukum yang menentukan kedudukan hukum pewaris dengan ahli waris terhadap harta yang akan diwariskan pada saat pewaris telah meninggal maupun ketika masih hidup. ${ }^{15}$ Kaidah-kaidah inilah yang mengatur hubungan hukum yang menentukan hak yang didapatkan oleh ahli waris dan kewajiban apa yang menjadi tanggung jawab ahli waris. Memperhatikan nilai-nilai hukum waris adat dalam hukum adat Bali seperti apa yang diuraikan di atas, maka sesuai dengan penelitian yang dilakukan disini, hal pokok yang diatur dalam hukum adat khususnya hukum adat Bali adalah mengenai hukum waris. Istilah "waris" berasal dari bahasa arab yang telah menjadi bahasa Indonesia yang artinya orang yang menerima harta pusaka dari orang yang telah meninggal. Hukum waris merupakan peraturan-peraturan yang mengatur unsur-unsur dalam pewarisan, yang

14 Ter Haar, 1982,Asas-asas dan Susunan Hukum Adat, Diterjemhakan oleh K. Ng. Soebekti Proesponoto, Pradnya Paramita, Jakarta, hlm.231.

15 I Gde Pudja , 1982, Pedoman Penghayatan Dan Pengamalan Pancasila dan Ajaran Hindu Dharma, Cetakan Keempat, Direktorat Jendral Bimbingan Masyarakat Hindu dan Budha Departeman Agama RI. hlm.50. 
merupakan sebuah proses pengalihan harta kekayaan baik itu berupa material maupun non material. Ayu Putu Nantri memberikan pengertian tentang hukum waris adat :

"Suatu proses penerusan dari pewaris kepada ahli waris tentang barangbarang materiil maupun barang-barang immateriil yang mana hal ini berarti bahwa penerusan ini menyangkut penerusan hak-hak dan kewajibankewajiban". ${ }^{16}$

Warisan dalam masyarakat adat di Bali tidak hanya menyangkut tentang hak namun juga kewajiban-kewajiban pada leluhur, masyarakat, dan keluarga. Seseorang yang menjadi ahli waris dalam sistem kewarisan individual seperti ini akan menerima tidak hanya hak terhadap harta benda milik si pewaris namun juga akan menerima kewajiban-kewajiban dari si pewaris. Ahli waris dalam masyarakat adat Bali yang dalam sistem kewarisan mayorat adalah anak laki-laki yang tertua atau sering disebut purusa juga menerima kewajiban sebagai kepala keluarga setelah orang tuanya meninggal. Pada saat seperti ini seorang purusa juga memiliki tanggung jawab untuk memelihara adik-adiknya dan peninggalan harta pusaka yang tidak dapat dibagi-baginya seperti pura keluarga (sanggah/merajan). Apabila ahli waris menerima harta warisan yang tidak dapat dibagi-bagi atau dalam pengertian lain harta warisan tersebut adalah milik bersama para

Ayu Putu Nantri, 1982,Kedudukan Ahli Waris Yang Beralih Agama Menurut Hukum Adat Waris di Kabupaten Badung, Laporan Penelitian, Fakultas Hukum Universitas Udayana, Denpasar, hlm.1. ahli waris, maka dapat dikatakan dalam hal ini juga berlaku kewarisan kolektif sehingga dapat dimengerti bahwa pada masyarakat adat Bali, menurut Tjokorde Istri Putra Astiti, dkk :

"Masyarakat adat Bali yang umumnya menganut susunan kekeluargaan patrilineal, akan berlaku ketiga sistem kewarisan yakni individual, kolektif dan mayorat". ${ }^{17}$

Berdasarkan uraian di atas dapat dikemukakan bahwa pengertian dan hakekat warisan menurut hukum adat Bali adalah proses pelimpahan harta kekayaan, hutang, kewajiban dan tanggung jawab dari pewaris kepadaahliwarisdenganmempertimbangkan kedudukannya apakah sebagai purusa atau tidak sebagai purusa. Pengertian dan hakekat warisan seperti tersebut akan semakin jelas bila dikaji berdasarkan teori sistem hukum yang pada dasarnya menegaskan "bekerjanya suatu sistem hukum merupakan hasil interaksi yang dinamis dari substansi, struktur, dan kultur atau budaya". Hakekat warisan terdapat pada aturan hukum berupa awig-awig dan keputusan Majelis Utama Desa Pakraman (MUDP) yang merupakan substansi dari sistem hukum dan ditegakkan oleh desa pakraman dan Majelis Utama Desa Pakraman (MUDP) sebagai struktur dalam sistem hukum, serta keadaan ini sudah cocok dengan sistem kekeluargaan patrileneal seperti yang terjadi pada masyarakat adat Bali, dimana berlaku tiga sistem kewarisan

Tjkorde Istri Putra Astiti, I Wayan Beni, Ni Nyoman Sukerti, 1984, Hukum Adat Dua (Bagian Dua), Biro Dokumentasi dan Publikasi Hukum Fakultas Hukum Universitas Udayana, Denpasar, hlm.51. 
yakni individual, kolektif dan mayorat yang merupakan cerminan dari pengaruh budaya sistem kekeluargaan dan Tri Hita Karana terhadap sistem hukum adat Bali .

Bila dilihat dari hak (swadikara) yang didapatkan seorang ahli waris berupa warisan menurut hukum adat Bali, warisan dapat dibedakan berdasarkan sifatnya yang dapat dibagi dan tidak dapat dibagi. Warisan yang dapat dibagi adalah seperti tanah, harta materi seperti kendaraan, rumah, uang, dan lainlain. Warisan yang tidak dapat dibagi adalah tempat suci dan karang desa (tanah milik desa adat) yang didapatkan karena menjadi krama atau warga dari desa adat/pakraman). Sifat warisan ini pun dapat dibedakan dari segi ekonomi. Ada warisan yang memiliki nilai ekonomi seperti tanah produktif (sawah, ladang), tabungan/deposito, dan lain-lain. Warisan yang tidak memiliki nilai ekonomi adalah seperti tempat suci (pura keluarga), kewajiban (swadharma) kepada keluarga, leluhur dan masyarakat adat, juga kewajiban berupa ayahan (kewajiban kerja dalam kegiatan desa pakraman) dan pembayaran iuran (urunan).

Dalam hubungan kekeluargaan ini terdapat unsur-unsur yang menjadi pelaku dalam proses pewarisan, selain unsur pelaku juga terdapat unsur berupa harta kekayaan yang menjadi obyek pewarisan. Bila dirumuskan, maka unsur-unsur yang harus ada dalam pewarisan terdiri dari pewaris, warisan, dan ahli waris yang diuraikan sebagai berikut :

\section{Pewaris}

Pengertian pewaris didalam Hukum Waris Adat menurut Hilman Hadikusuma, Seseorang yang dapat melimpahkan atau mengalihkan harta benda yang dimilikinya, apakah harta itu merupakan harta yang dapat dibagibagi atau tidak dapat dibagi-bagi. Harta benda ini kemudian akan menjadi hak milik orang yang diwariskan dalam hal ini adalah keturunannya. ${ }^{18}$

Sesorang yang dapat digolongkan sebagai pewaris dalam hal ini orang tua kandung, saudara dari orang tua kandung, kakek dan nenek atau orang tua dari bapak dan ibu kandung. Sesuatu yang pasti menyebabkan seseorang memupunyai status sebagai pewaris adalah karena memiliki harta benda yang akan diwariskan. Selanjutnya Tjokorde Istri Putra Astiti dkk berpendapat bahwa :

Orang ketika meninggalnya meninggalkan harta warisan atau harta peninggalan yang akan beralih atau diteruskan kepada ahli warisnya. ${ }^{19}$

\section{Harta Warisan}

Harta warisan adalah hal pokok yang menyebabkan proses pewarisan itu dapat berlangsung. Harta kekayaan yang ditinggalkan atau diwariskan oleh pewaris pada saat telah meninggal dunia maupun pada saat masih hidup inilah yang disebut dengan harta warisan. Harta warisan yang dimaksudkan disini tidak hanya harta yang menunjukan nilai ekonomi, namun juga termasuk harta yang menunjukan nilai keagamaan. Soeripto ${ }^{20}$ menguraikan

18 Hilman Hadikusuma, 1994, Hukum Waris Indonesia, Menurut Perundangan Hukum Adat, Hukum Agama Hindu- Islam, Citra Aditya Bakti, Bandung,hlm.9-10.

19 Tjokorde Istri Putra Astiti,I Wayan Beni, Ni Nyoman Sukerti, op.cit., hlm.50.

20 Soeripto, op. cit., hlm. 92. 
bagaimana keluarga yang menganut agama Hindu di Bali juga mempunyai harta kekayaan keluarga yang dapat berupa harta benda yang mengandung nilai-nilai religius yang ditunjukan karena hubungannya dengan kegiatan atau ritual keagamaan, dan juga harta yang tidak termasuk dalam kelompok yang memiliki nilai-nilai keagamaan seperti harta akas kaya, harta jiwa dana, harta druwe gabro.

Hilman Hadikusuma berpendapat harta warisan adalah :

"Semua harta berupa hak-hak dan kewajiban-kewajiban yang beralih penguasaan atau pemilikannya setelah pewaris meninggal dunia kepada ahli waris". ${ }^{21}$

Diskusi Hukum Waris Adat di Bali menghasilkan kesimpulan yang menyatakakanharta warisan adalah :harta pusaka, harta bawaan atau harta yang telah menjadi milik perempuan dan laki-laki sebelum perkawinan, yang didapatkan dari usaha sendiri atau diberikan oleh keluarga yang dibawa pada saat melangsungkan perkawinan, dan harta perkawinan yaitu harta yang dihasilkan atau didapatkan pada saat perkawinan. Harta ini sering disebut guna kaya. Hak yang didapatkan dari masyarakat adat juga digolongkan sebagai harta seperti misalnya hak terhadap penggunaan kuburan. ${ }^{22}$

Hilman Hadikusuma,op.cit, hlm.33.

Lembaga Pembinaan Hukum Nasional, 1997, Kedudukan Wanita Dalam Hukum Waris Menurut Hukum Adat Bali,Hasil-Hasil Diskusi Hukum Adat Waris Di Bali, Sekretariat Panitia Diskusi Hukum Adat Waris di Denpasar, hlm.4.

\section{Ahli Waris}

Di dalam kehidupan masyarakat di Indonesia para ahli waris tidak terlepas dari pengaruh susunan kekerabatannya yang patrilineal, matrilineal dan parental atau bilateral. ${ }^{23}$ Masyarakat yang menganut sistem kekeluargaan patrileneal mengutamakan azas dimana anak laki-laki diposisikan sebagai penerusgarisketurunansebagaisesorangyang berhak untuk menjadi ahli waris, sementara anak perempuan tidak diutamakan sebagai ahli waris. Kemungkinan wanita menjadi ahli waris kecil sekali, kecuali dikarenakan ia sebagai janda dan almarhum pewaris menggunakan hak pakainya atas peninggalan harta suaminya atau ia sebagai anak wanita yang diberi kedudukan sebagai anak pria (pengganti) dengan melakukan perkawinan "ambil pria". ${ }^{24}$ Pada masyarakat adat yang mempertahankan susunan kekerabatan dari garis keibuan (matrilineal) yang berhak menjadi ahli waris adalah wanita, sedangkan anak-anak pria ideologinya bukan pewaris. ${ }^{25}$ Untuk susunan masyarakat yang bersifat keorangtuaan (parental) atau yang menarik garis keturunan dari dua sisi, yaitu dari pihak ayah dan dari pihak ibu (bilateral), tidak membedakan kedudukan anak pria maupun anak wanita sebagai ahli waris.

HukumadatBali mengelompokkan ahli waris menjadi beberapa kelompok, dimana menurut Soerjono Soekanto,menyebutkan ahli warsi dalam hukum adat Bali menggunakan empat macam kelompok keutamaan yakni :26

\footnotetext{
Hilman Hadikusuma, op. Cit. hlm.63.

ibid.

Ibid, hlm. 96.

Soerjono Sooekanto dan Sulaiman B. Taneko, 1994, Hukum Adat Indonesia, CV. Rajawali, Jakarta, hlm.287.
} 
a. Kelompok keutamaan I : keturunan pewaris

b. Kelompok keutamaan II : orang tua pewaris

c. Kelompok keutamaan III : saudarasaudara pewaris dan keturunanya

d. Kelompok keutamaan IV : kakek dan nenek pewaris.

Keturunan dari pewaris adalah disebut sebagai ahli waris utama yang memiliki hak pertama dalam pewarisan, sedangkan ahli waris yang lain baru memiliki hakatas harta warisan manakalaorang tua yang meninggal itu tidak memiliki anak, artinya apabila seorang anak lebih dahulu meninggal dunia maka yang mempunyai hak mendapatkan warisan dari anak yang meninggal tersebut adalah anaknya sendiri. Manakala seorang anak pewaris tadi tidak memiliki keturunan lagi barulah yang memiliki hak mewaris adalah orang tuanya sendirisebagai kelompok keutamaan II, kemudian apabila orang tua pewaris sudah meninggal dunia maka sebagai ahli waris adalah kelompok keutamaan III yakni saudara-saudara pewaris dan keturunannya. Demikian seterusnya apabilasaudara-saudaradari pewaris dan keturunannya sudah tidak ada lagi sehingga ahli waris penggantinya adalah kakek dan nenek dari si pewaris tersebut.Pada umumnya masyarakat Bali menganut sistem kekeluargaan patrilineal, sehingga dalam hukum adat di Bali, I Gde Pudja, mengatakan persyaratan-persyaratan sebagai ahli waris adalah: ${ }^{27}$

a) Adanya hubungan darah antara seseorang yang menjadi ahli waris

I Gde Pudja op. cit. hlm.42. dengan pewaris, seperti anak kandung dari pewaris

b) Anak tersebut adalah seorang anak yang memiliki jenis kelamin laki-laki

c) Apabila pewaris tidak memiliki anak kandung, maka yang juga memiliki hak adalah seseorang yang bukan anak kandung (anak angkat)

d) Apabila pewaris tidak memiliki anak, maka dalam hukum Hindu memberikan kesempatan kepada kelompok atau golongan tertentu yang mempunyai hubungan kekerabatan dengan pewaris, dan sesuai dengan ketentuan yang diatur dalam hukum Hindu.

Penjelasan mengenai hukum warisan di atas belum ada yang membicarakan mengenai hak warisan dari seorang dahatua. Pengertian daha tua menurut Korn adalah anak wanita yang tidak pernah kawin. ${ }^{28}$ Dalam daftar kata buku Hak Mewaris Perempuan Dalam Hukum Adat Bali Sebuah Studi Kritis karya Ni Nyoman Sukerti kata deha tua diartikan sebagai sebutan dan status bagi anak perempuan yang tidak kawin sampai tua. ${ }^{29}$ Dari beberapa penjelasan mengenai daha tua tersebut penulis berpendapat daha adalah perempuan dewasa secara biologis dengan ciri-ciri mulainya mentruasi, umur mulai dari belasan tahun sampai batas umur dikatakan sebagai tua atau usia lanjut, dimana menurut pasal 1 Undang-Undang no. 4 tahun 1965, Seseorang dikatakan sebagai orang jompo atau usia lanjut setelah yang bersangkutan

28 V.E Korn, 1972, Hukum Adat Waris Bali (Het Adatrech van Bali bab-IX) terjemahan I Wayan Pangkat, Biro Dokumentasi Dan Pubikasi Hukum, Fakultas Hukum dan Masyarakat, Univ. Udayana, Denpasar, hlm.46.

29 Ni Nyoman Sukerti, op. cit., hlm.131. 
mencapai usia 55 tahun, tidak mempunyai atau tidak berdaya mencari nafkah sendiri untuk keperluan hidupnya sehari-hari, dan menerima nafkah dari orang lain. Selain itu dewasa juga dapat dikaji dari perspektif psikologi dan hukum. Secara psikologis perempuan dikatakan dewasa ketika telah dapat bertanggung jawab atas perbuatannya sendiri terhadap orang lain, lingkungannya, dan dirinya sendiri. Sedangan dari perspektif hukum Indonesia perempuan disebut dewasa adalah pada saat perempuan itu berada dari rentang umur mulai 18 tahun, dimana ketika perempuan berada pada umur di bawah 18 tahun disebut sebagai anak di bawah umur. Setelah perempuan ada pada umur yang disebut dewasa menurut hukum barulah perempuan ini dapat diadili secara hukum positif manakala mereka melakukan perbuatan yang mengandung konskwensi hukum. Hal yang paling substansi seorang perempuan dewasa disebut daha tua adalah karena statusnya yang tidak pernah kawin. Pada saat seorang perempuan dewasa telah mencapai batas akhir umur untuk kawin yang ditandai berakhirnya kemampuan reproduksi secara biologis (kira-kira setelah 50 tahun) belum juga melakukan perkawinan, keadaan inilah yang disebut dengan status daha tua. Jadi daha tua dapat dipahami sebagai seorang perempuan dewasa dengan rentang umur mulai kira-kira dari 50 tahun sampai meninggal dengan status belum pernah melakukan perkawinan.

Keputusan Mahkamah Agung yang telah menetapkan ketentuan ahli waris menurut hukum adat, khususnya ahli waris anak perempuan, terdapat dalam putusan MahkamahAgungRepublikIndonesiaNomor
4766K/Pdt/1998 tertanggal 16 November 1999, dalam putusannya menyatakan bahwa anak perempuan di Bali berhak atas harta peninggalan dari pewaris. Melalui keputusan tersebut menjelaskan bahwa anak perempuan berhak menerima harta warisan dari pewaris dan karena itu anak perempuan harus dianggap sebagai ahli waris. Gender menjelaskan perbedaanperanan antara pria dengan wanita, yang dibentuk oleh masayarakat sesuai dengan norma sosial budaya masyarakat. Menurut hukum adat masyarakat patrilineal, sudah sangat banyak peranan yang dimainkan oleh kaum wanita disegala bidang sejak dulu. ${ }^{30}$

Dalam hukum adat Bali, anak perempuan/daha tua bukanlah ahli waris, hal ini sejalan dengan sistem kekerabatan yang berlaku dalam masyarakat adat Bali, yaitu Patrilineal atau kepurusa, dimana kewajiban anak laki-lakilah yang melanjutkan segala kewajiban tersebut baik yang berhubungan dengan tempat pemujaan/persembahyangan yang sering disebut dengan merajan/sanggah, segala kewajiban pawongan (kemanusiaan) lainnya dalam kaitannya dengan keluarga sebagai bagian dari masyarakat adat, serta berbagai kewajiban yang lainnya, yang berhubungan dengan orang tua/ leluhur. Perempuan dianggap kurang patut untuk mendapatkan warisan, kurang lebih karena kedudukannya tidak sebagai purusa, karena kewajiban yang dilakukan oleh perempuan/daha tua terhadap keluarga dan masyarakattidak

30 Gek Ela Kumala Parwita, Majalah Balisruti, http:// www.balisruti.or.id, (diakes12-09-2014,14.00 WITA), hlm.26. 
seperti laki-laki yang berkedudukan sebagai purusa, sudah sewajarnyalah perempuan/ daha tua tidak mendapatkan warisan sama seperti purusa. Namun jikalau seorang perempuan yang menurut hukum adat Bali dapat diangkat sebagai purusa dalam kasus sentana rajeg, maka hak mewarisnya pun akan sama dengan laki-laki yang berstatus purusa.

Mengenai tanggung jawab daha tua terhadap keluarga dan masyarakatadalah sama dengan anak perempuan yang belum kawin, namun tidak sama dengan lakilaki, baik yang berstatus sebagai purusa maupun tidak. Tanggung jawab inilah yang menyebabkan adanya perbedaan pemberian hak kepada anak perempuan maupun daha tua.Pada masyarakat adat Bali, anak perempuan bukanlah sebagai ahli waris, namun dapat menjadi ahli waris apabila statusnya diangkat menjadi laki-laki secara hukum adat Bali dikenal dengan istilah Sentana Rajeg, sepanjang ia tidak kawin keluar.Walaupun anak perempuan bukanlah merupakan ahli waris,akan tetapi ia berhak menikmati atas bagian dari harta warisan selama tidak putus haknya. Kehilangan hak menikmati dari harta warisan itu terjadi apabila anak perempuan kawin keluar. Jadi, jika kemudian anak perempuan kawin keluar, bagian yang dinikmati itu harus diserahkan kembali kepada keluarganya dan harta warisan ini tidak boleh dibawa serta masuk ke perkawinan. Namun, Gde Panetje berpendapat bahwa ;

selama anak perempuan belum kawin pun ia tidak boleh melakukan tindakan yang dapat dianggap tindakan pemilikan terhadap bagiannya, kecuali atas hasilnya misalnya ia tidak boleh menjual, menggadaikan atau membebankan atas hutang atau mengalihkannya tanpa persetujuan ahli waris laki-laki lainnya atau ahli waris pengawas yaitu paman atau sepupu laki-laki dari garis laki-laki (purusa). ${ }^{31}$ Selain uraian di atas, kedudukan perempuan/daha tua juga dapat dilihat pada keputusan pengadilan sejak jaman Raad Kertha (Raad Kertha Singaraja Tanggal 19 Juli 1937 Nomor 41/Sipil) sampai jaman setelah Pengadilan negeri terbentuk (Keputusan Pengadilan Negeri Negara tanggal 29 Juni 1953 Nomor 20/Sipil), ${ }^{32}$ yang isinya menyatakan bahwa anak perempuan yang selama hidupnya tidak melakukan perkawinan (daha tua), haknya untuk menikmati harta warisan tetap berlangsung selama ia masih hidup. Dengan demikian, anak wanita berhak atas bagian harta warisan keluarga, bukan sebagai pemilik, melainkan sebagai barang yang dinikmati. Bagian yang berhak diterima anak perempuan adalah satu berbanding dua dibandingkan dengan bagian yang diterima anak lakilaki sesuai dengan konsep rembat sesuhun. Konsep rembat sesuhun juga dikenal dengan konsep ategen asuhun. Ategen yang artinya sepikul adalah dua bagian untuk anak lakilaki mengingat tanggung jawabnya dalam keluarga yang lebih besar, sedangkan asuhun yang artinya sejunjungan (menaruh barang di atas kepala) adalah satu bagian untuk anak wanita mengingat tanggung jawabnya dalam keluarga yang lebih kecil.

\footnotetext{
31 I Gede Panetje, op. Cit, , hlm.111

32 Gde Panetje, op. cit, hlm.170.
} 
Sesuai dengan jenis haknya, yaitu hak untuk menikmati, bukan sebagai hak milik, maka ia tidak boleh melakukan tindakan kepemilikan terhadap harta tersebut seperti menjual, menggadaikan, membebankan atas hutang ataupun mengalihkan kepada orang lain, kecuali mendapat persetujuan dari ahli waris atau mendapat ijin dari pengadilan. Hal seperti ini pernah diputuskan oleh Raad Kertha Karangasem Tanggal 3 Nopember 1936, Nomor 33/Sipil. ${ }^{33}$

Kajian ini membuktikan telah terjadi keadilan yang diharapkan apabila dianalisis menggunakan teori dari Aristoteles. Dilihat dari teori ini perempuan semestinya diperlakukan sama dengan laki-laki karena sama-sama dapat melaksanakan kewajiban. Namunjugasemestinyadiperlakukanberbeda karena adanya perbedaan jenis kelamin. Perbedaan jenis kelamin menyebabkan fungsi perempuan dalam kehidupan sebagai manusia menjadi berbeda dengan laki-laki. Keadaan alami perempuan yang memiliki kemampuan untuk berketurunan atau mempunyai anak tidak dimiliki oleh laki-laki. Namun perempuan tidak dapat melaksanakan kemampuan alaminya untuk berketurunan atau mempunyai anak tanpa adanya pembuahan dari laki-laki. Perempuan dan laki-laki memiliki kemampuan dan fungsi alami yang berbeda walaupun sama-sama sebagai manusia. Hubungannya dengan hak mendapatkan warisan, perempuan dapat saja menerima hak yang sama dengan laki-laki apabila peran dan fungsi yang dilakukan oleh perempuan itu adalah sama. Kenyataanya dalam masyarakat adat Bali, perempuan

33 Gde Panetje, op. cit, hlm.111. baru dapat mengambil peran seperti lakilaki ketika dalam sebuah keluarga tidak mendapatkan keturunan laki-laki yang akan dijadikan purusa (penerus garis keturunan). Pada saat itulah perempuandapat diangkat statusnya menjadi sentana rajegyang mengambil peran sebagai purusa melalui perkawinan, dimana laki-laki atau suaminya berstatus sebagai pradana.

Mengenai daha tua yang tidak berstatus purusa karena bukan laki-laki dan sentana rajeg, tentunya tidak melaksanakan kewajiban sebagai penerus garis keturunan, kewajiban meneruskan pelaksanaan ritual keagamaan di Sanggah atau Pemerajan, dan kewajiban sebagai krama ngarep di desa pakraman. Dengan demikian dapat dianggap adil ketika daha tua tidak mendapatkan hak warisan sama dengan lakilaki (purusa). Walaupun demikian seorang daha tua tidak pernah kehilangan haknya untuk menggunakan harta kekayaan orang tuanya (guna kaya) sebagai jiwa dana atau harta kekayaan yang dipakai untuk menjaga kelangsungan hidupnya. Namun jika daha tua ini adalah seorang anak tunggal, maka secara otomatis menjadi sentana rajeg dalam pengertian ahli waris satu-satunya. Daha tua dalam kasus seperti ini juga dapat dikatakan sebagai purusa, karena sebagai penerus tanggung jawab dan kewajiban (swadharna) pada keluarga dan masyarakat.

Pada saat daha tua berstatus sebagai purusa, hak warisnya sama dengan laki-laki dan perempuan yang berstatus purusa.Hal inidisebabkan oleh karena kewajibannya yang sama dengan laki-laki dan perempuan yang berstatus purusa. Namun jika daha tua ini bukan anak tunggal yang memiliki 
saudara laki-laki/perempuan, maka statusnya bukanlah sentana rajeg yang berkedudukan sebagai pradana dan haknya dalam pewarisan adalah sama dengan anak perempuan muda yang belum kawin.

Namun demikian peranan struktur (desa pakraman dan MUDP) dalam teori sistem hukum disini adalah memberikan keadilan kepada daha tua yang dituangkan dalam bentuk aturan hukum (awig-awig dan keputusan MUDP) dengan memperhatian budaya dalam masyarakat Bali dan perjuangan kesetaraan gender seperti yang dimaksudkan dalam teori feminisme pada halaman 23. Penggunaan teori feminisme adalah untuk mengukur kesetaraan antara perempuan dan laki-laki yang didasarkan pada kemiripan/kesamaan (similiarities), dan perlakuan khusus (special treatment) terhadap perbedaan laki-laki dan perempuan agar masing-masing tetap dapat mencapai tujuan fungsionalnya.

\section{PENUTUP}

\subsection{Simpulan}

Berdasarkan hasil kajian yang telah dilakukan maka dapat disimpulkan beberapa hal diantaranya:

1. Hakekat pewarisan menurut hukum adat Bali adalah proses pelimpahan harta kekayaan, hutang, kewajiban dan tanggung jawab dari pewaris kepada ahli waris dengan mempertimbangkan kedudukannya apakah sebagai purusa atau tidak sebagai purusa. Hal ini sesuai dengan sistem kekeluargaan yang yang dilakukan atau dianut oleh masyarakat adat di Bali yaitusistem patrilineal, dimana berlaku tiga sistem kewarisan yakni individual, kolektif dan mayorat. Hak (swadikara) yang didapatkan seorang ahli waris berupa warisan dibedakan berdasarkan sifatnya yang dapat dibagi dan tidak dapat dibagi. Warisan yang dapat dibagi adalah seperti tanah, harta materi (kendaraan, rumah, uang, dan lain-lain). Warisan yang tidak dapat dibagi adalah tempat suci dan karang desa (tanah milik desa adat) yang didapatkan karena menjadi krama atau warga dari desa adat/pakraman). Sifat warisan ini pun dapat dibedakan dari segi ekonomi. Ada warisan yang memiliki nilai ekonomi seperti tanah produktif (sawah, ladang), tabungan/deposito, dan lain-lain. Warisan yang tidak memiliki nilai ekonomi adalah seperti tempat suci (pura keluarga), kewajiban (swadharma) kepada keluarga, leluhur dan masyarakat adat, juga kewajiban berupa ayahan (kewajiban kerja dalam kegiatan desa pakraman) dan pembayaran iuran (urunan).Unsurunsur yang harus ada dalam pewarisan terdiri dari pewaris, warisan, dan ahli waris. Sesuai dengan sistem hukum adat Bali, pembagian warisan dapat berlangsung karena adanya struktur yang memiliki wewenang untuk mengatur pembagian warisan tersebut seperti desa pakraman dan Majelis Utama Desa Pakraman (MUDP) Bali.

2. Kedudukan daha tua dalam pewarisan menurut hukum adat Bali ditentukan oleh statusnya sebagai purusa/sentana rajeg atau sebagai pradana. Apabila 
seorang daha tua tidak memiliki saudara (anak tunggal), haknya terhadap warisan adalah sama dengan purusa/sentana rajeg. Namun apabila daha tua tidak berstatus purusal sentana rajeg maka warisan yang dapat diterimanyamenurut hukum adat Bali seperti yang terdapat dalam awig-awigdan pustaka-pustaka mengenai hukum adat Bali adalah sama dengan perempuan muda yang belum kawin(pradana), yaitu hanya berhak menggunakan harta guna kaya dari orang tuanya sebagai jiwa dana atau harta kekayaan yang digunakan untuk menjaga kelangsungan hidupnya. Perkembangan selanjutnya pesamuhan MUDP memutuskan, seorang perempuanberhak menerima setengah dari hak waris purusa setelah dipotong 1/3 untuk harta pusaka dan kepentingan pelestarian sepanjang perempuan ini tidak pindah agama dan durhaka pada orang tuanya. Warisan yang diterima daha tua juga tergantung pada peran struktur yang memiliki wewenang dalam mengatur pemberian warisan seperti Desa Pakraman dan Majelis Utama Desa. Pakraman, dan pemahaman masyarakat adat pada hukum adat mengenai warisan yang selalu berusaha untuk menegakan nilai-nilai keadilan.

\subsection{Saran}

1. Kepada desa adat disarankan agar mengadopsi keputusan pesamuhan agung dalam awig-awig sebagaimana tertuang dalam keputuasn Majelis Utama Desa Pakraman.

2. Kepada para penegak hukum, khususnya hakim dan notaris agar menjadikan hasil keputusan Majelis Utama Desa Pakraman sebagai acuan dalam menyelesaikan masalah warisan yang dihadapi.

\section{DAFTAR PUSTAKA}

\section{Buku :}

Aripta Wibawa, Made, 2006, Wanita Hindu Sebuah Emansipasi Kebablasan, PT. Empat Warna Komunikasi, Denpasar. Hadikusuma,Hilman,1994, Hukum Waris Indonesia, Menurut Perundangan Hukum Adat, Hukum Agama HinduIslam, Citra Aditya Bakti, Bandung.

Lembaga Pembinaan Hukum Nasional, 1997, Kedudukan Wanita Dalam Hukum Waris Menurut Hukum Adat Bali,Hasil-Hasil Diskusi Hukum Adat Waris Di Bali, Sekretariat Panitia Diskusi Hukum Adat Waris di Denpasar.

Majelis Utama Desa Pakraman (MUDP) Bali, 2010, Himpunan Hasil-Hasil Pasamuhan Agung III MDP Bali, MUDP, Denpasar.

Nantri,AyuPutu, 1982,Kedudukan Ahli Waris Yang Beralih Agama Menurut Hukum Adat Waris di Kabupaten Badung, Laporan Penelitian, Fakultas Hukum Universitas Udayana, Denpasar.

Panetje, Gde, Aneka Catatan Tentang Hukum Adat Bali, CV. Kayumas Agung, Denpasar. 
Peter Mahmud Marzuki, 2008, Penelitian Hukum, Kencana Prenada Media Group, Jakarta.

Pudja,I Gde,1982, Pedoman Penghayatan Dan Pengamalan Pancasila dan Ajaran Hindu Dharma, Cetakan Keempat, Direktorat Jendral Bimbingan Masyarakat Hindu dan Budha Departeman Agama RI.

Putra Astiti, Tjkorde Istri , Beni, I Wayan, Sukerti,Ni Nyoman, 1984, Hukum Adat Dua (Bagian Dua), Biro Dokumentasi dan Publikasi Hukum Fakultas Hukum Universitas Udayana, Denpasar.

Soepomo, 2000, Bab-Bab Tentang Hukum Adat, Pradnya Paramita, Jakarta.

Soeripto, 1983, Beberapa Bab tentang Hukum Adat Bali, Fakultas Hukum Fakultas Hukum Universitas Negeri Jember, Jember.

Soerjono Sooekanto dan Sulaiman B. Taneko, 1994, Hukum Adat Indonesia, CV. Rajawali, Jakarta.

Suharso dan Ana Retno Ningsih, 2014, Kamus Besar Bahasa Indonesia, Edisi Lux, CV. Widya Karya, Semarang.

Sukerti, Ni Nyoman, 2012, Hak Mewaris Perempuan Dalam Hukum Adat Bali Sebuah Studi Kritis, Udayana University Press, Denpasar.

Ter Haar, 1982,Asas-asas dan Susunan Hukum Adat, Diterjemhakan oleh K. Ng. Soebekti Proesponoto, Pradnya Paramita, Jakarta.

V.E Korn, 1972, Hukum Adat Waris Bali (Het Adatrech van Bali bab-IX) terjemahan I Wayan Pangkat, Biro Dokumentasi Dan Pubikasi Hukum, Fakultas Hukum dan Masyarakat, Univ. Udayana, Denpasar.
Wirjono Prodjodikoro, 1986, Asas-Asas Hukum Pidana Indonesia, PT.Eresco Bandung.

\section{Internet :}

Gek Ela Kumala Parwita, Majalah Balisruti, http://www.balisruti.or.id

Jalius HR, Pengertian Hakekat, https:// jalius12.wordpress.com/2010/12/06/ pengertian-hakekat. 